\title{
ANALYTICAL SOLUTION FOR SIMPLY SUPPORTED LAMINATED COMPOSITE PLATES BASED ON PARTIAL LAYERWISE THEORY
}

\author{
Marina Rakočević \\ University of Montenegro, Faculty of Civil Engineering, Montenegro
}

Anisotropic composition of layered composite plates requires more accurate mathematical and calculation models. By applying Reddy's layerwise theory we can cover a wide range of problems of layered composite plates with arbitrary arrangement of layers through the plate thickness. The analytical method of solving bending equations in Layerwise Theory is based on the assumed displacement field in the form of the double trigonometric Fourier's series. The analytical solution can be used as a test solution for solutions obtained by using numerical methods, including finite element method. For Partial Layerwise Theory, the paper presents the equations of bending for laminated composite plates and the algorithm for calculation of deflections and stresses in an arbitrary cross section of a simply supported rectangular plate loaded with distributed load. On the basis of the algorithm presented in this paper, author has prepared Fortran program called ANSLACOP (ANalytical SOlution of LAminated COmposite Plates), whose structure will be presented in the paper. It is presented that the solution obtained by using this program very quickly converges depending on the adopted number of members of double trigonometric series.

Key words: Laminated composite plate, Layer, Bending, Partial Layerwise theory, Analytical solution

\section{INTRODUCTION}

Layered composite plates, with layers carrying in different directions in the plane plate, wherein each of the layers contains parallel fibers of a material in the basic of the other material that carry only in one direction, show extremely anisotropic behavior. For more accurate determination of the stress-strain components it is necessery to use theories which conduct analysis at the level of layer or the level of fiber/basic compaund.

Theoretical analysis of the layered composite plates can be conducted using the Equivalent Single Layer Theory (ESLT) and the Layerwise Theory [02],[01],[08].

ESLT treates layered composite plate as static equivalent to a single layer. Single-classical theories include classical theorie and shear theory of the first, second and higher order. The simplest ESLT is the Classical Laminated Plate Theory (CLPT), which is based on the application of Kirchoff's theory of plates. This theory is applied for the calculation of thin homogeneous plate. For moderatelly thick and thick plates with a high degree of anisotropy, a solution obtained by applying this theory is not satisfactory accurate because the calculation does not introduce deformation caused by shear. The next onelayer theory is the First-Order Shear Deformation Theory (FSDT) that resulted from the limited CLPT. FSDT introduces a constant sliding across the plate thickness. Higher order shear theory (Second-Order Plate Theory, Third-Order Plate Theory) constant shear through the thickness of the plate is replaceing by shear assumed in the form of higher order polynomial (quadratic, cubic).

For theoretical analysis of thick and moderately thick laminated composite plates layerwise theories are applied including the Generalized Layerwise Plate Theory (GLPT). In the GLPT considerations are implemented at the level of the layer, and depending on the adopted assumptions, the Partial Layerwise Theory and 
Full Layerwise Theory stand out. In the Partial Layerwise Theory is assumed that componental displacement perpendicular to the plane of the plate is constant through the thickness of the plate, $w=$ const. Follows that it is the componental displacement of $w$ function two coordinates $x$ and $y$. In this theory componental displacements in the plane plate, $u$ and $v$, can be obtained by superpositioning appropriate displacements defined in the medium plane plate, which are a function of the coordinates in the plane $(x, y)$, and added displacements defined as the product of nodal displacements and one-dimensional interpolation functions assigned to the function of coordinate $z$ at the thickness of the plate [01], [08]. In the Full Layerwise Theory is assumed to be componental displacements functions of all three coordinates $x, y$ and $z$ for which the mathematical model of this theory is much more complex than a mathematical model defined in the Partial Layerwise Theory.

Depending on the required accuracy and efficiency in stress deformation analysis of laminated composite plates the selection of the theory that will be used is made. If dealing with a thin layered composite panels it is most economical to apply ESLT, as for thick and moderately thick plates, and depending on the required accuracy and efficiency, Layerwise Theories are recommended.

After assumed displacement field of chosen theory it is necessary to define the connections of displacements and deformations, and after the connection of deformations and stresses, depending on the adopted physical and mechanical characteristics of the material, all within the observed coordinate system (x, y, z). By applying the principle of virtual displacements the corresponding equations of adopted theory are obtained [02], [01].

The equations of the theory can be solved analytically or numerically [05]. Analytical solutions are sought in the form of trigonometric functions that define the primary variable of the relevant theory. In addition to closed solutions, numerical solutions can be obtained by applying numerical methods, such as finite element method. Numerical solutions of primary variables are obtained for a pre-defined points of the layered composite plate in the plane and in the thickness of the plate depending on the adopted mathematical model. In the analysis of the accuracy of numeri- cal solutions, analytical solutions can be used as test solutions.

In this paper is presented an algorithm of Fortran's program ANLACOP which produces analytical solution to equation of the problem of bending simply supported laminated composite plates based on the assumptions of the Partial Layerwise Theory. Also, this paper is presented an analysis of convergence of results and comparison with existing results.

\section{MATEMATICAL MODEL OF THE PARTIAL LAYERWISE THEORY}

Reviews are carried out in the Cartesian coordinate system $(x, y, z)$, assuming that the layered composite plate comprises layers which are arbitrarily oriented in the plane of the plate $(x, y)$. Each of the layers contains parallel fibers that carry only in one direction.

In Partial Layerwise Theory it is assumed that the componental displacements of the arbitrary point of layered plate containing $\mathrm{N}$ orthotropic layers, [05]and [06], are defined by:

$$
\begin{aligned}
& u(x, y, z)=u(x, y)+U(x, y, z) \\
& v(x, y, z)=v(x, y)+V(x, y, z) \\
& w(x, y, z)=w(x, y)
\end{aligned}
$$

where $u(x, y), v(x, y), w(x, y)$ are displacements of the middle plane of the plate, while $U(x, y, z)$, $\mathrm{V}(\mathrm{x}, \mathrm{y}, \mathrm{z})$ are additional displacements through the plate thickness defined by following formulations:

$$
\begin{aligned}
& U(x, y, z)=\sum_{J=1}^{n} u^{J}(x, y) \psi^{J}(z) \\
& V(x, y, z)=\sum_{J=1}^{n} v^{J}(x, y) \psi^{J}(z)
\end{aligned}
$$

In the previous relation $u^{j}, v^{j}$ are the nodal displacements across the plate thickness, $\Psi \mathrm{j}(\mathrm{z})$ are continuous, general one-dimensional interpolation functions are defined by the thickness of the plate, and $n$ is number of nodes per plate thickness, Figure 1.

By applying the principle of virtual displacements the constitutive equations of the theory of bending of layered plates are formed, [05], [07] and [06]:

$$
\begin{array}{ll}
N_{x, x}+N_{x y, y}=0 & \\
N_{x y, x}+N_{y, y}=0 & N_{x, x}^{j}+N_{x y, y}^{j}-Q_{x}^{j}=0 \\
Q_{x, x}+Q_{y, y}+q=0 & N_{x y, x}^{j}+N_{y, y}^{j}-Q_{y}^{j}=0
\end{array}
$$




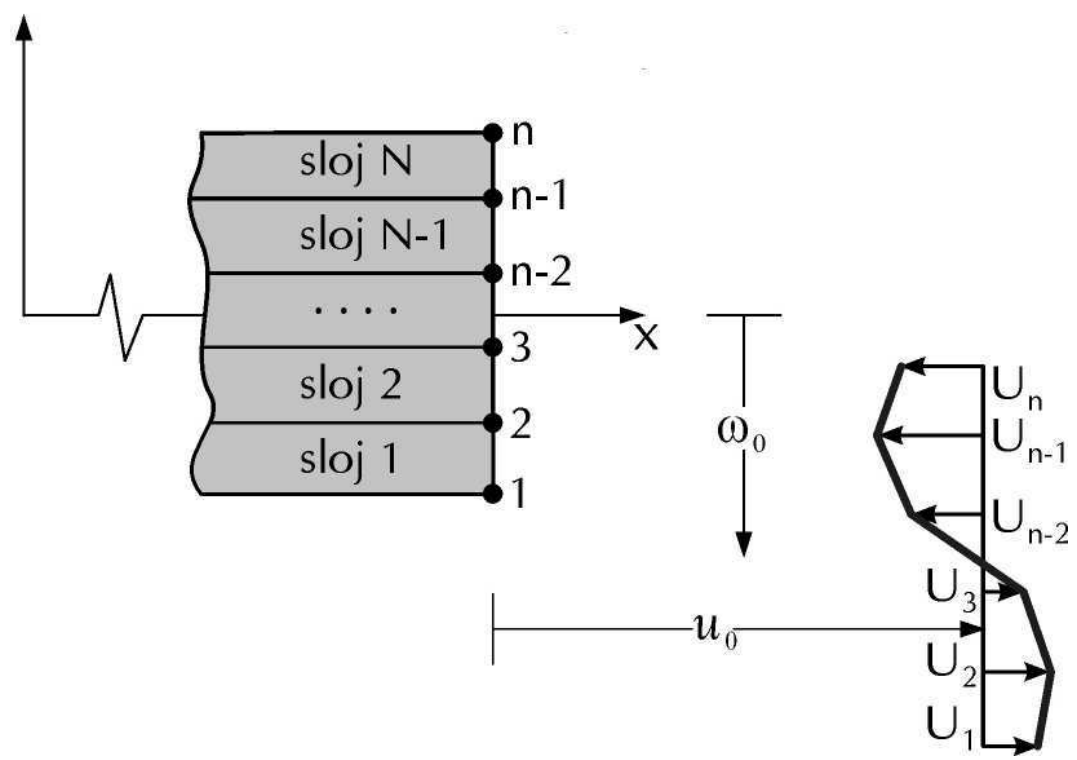

Figure 1: Displacement through the thickness of the plate

where:

$$
\begin{aligned}
& \left(N_{x}, N_{y}, N_{x y}\right)=\int_{-h / 2}^{h / 2}\left(\sigma_{x}, \sigma_{y}, \sigma_{x y}\right) d z \\
& \left(Q_{x}, Q_{y}\right)=\int_{-h / 2}^{h / 2}\left(\sigma_{x z}, \sigma_{y z}\right) d z \\
& \left(N_{x}^{J}, N_{y}^{J}, N_{x y}^{J}\right)=\int_{-h / 2}^{h / 2}\left(\sigma_{x}, \sigma_{y}, \sigma_{x y}\right) \psi^{J}(z) d z \\
& \left(Q_{x}^{J}, Q_{y}^{J}\right)=\int_{-h / 2}^{h / 2}\left(\sigma_{x z}, \sigma_{y z}\right) \psi,_{z}^{J} d z
\end{aligned}
$$

$\left(\sigma_{x}, \sigma_{y}, \sigma_{x y}, \sigma_{x z}, \sigma_{y z}\right)$ are components of stress vector, $j=1, \ldots, N$, while $q$ is the load perpendicular to the plane of the plate.

The paper adopts a linear interpolation along the two adjacent layers so the number of nodes through the thickness $\mathrm{n}$ is for one higher than the number of layers $\mathrm{N}$.

For the j-th orthotropic layer, the connection of stresses and deformations are given with:

$\left\{\begin{array}{c}\sigma_{x} \\ \sigma_{y} \\ \sigma_{x y} \\ \sigma_{x z} \\ \sigma_{y z}\end{array}\right\}=\left[\begin{array}{ccccc}\bar{Q}_{11} & \bar{Q}_{12} & \bar{Q}_{16} & 0 & 0 \\ \bar{Q}_{12} & \bar{Q}_{22} & \bar{Q}_{16} & 0 & 0 \\ \bar{Q}_{16} & \bar{Q}_{26} & \bar{Q}_{66} & 0 & 0 \\ 0 & 0 & 0 & \bar{Q}_{44} & \bar{Q}_{45} \\ 0 & 0 & 0 & \bar{Q}_{45} & \bar{Q}_{55}\end{array}\right\}^{(j)} x\left\{\begin{array}{l}\varepsilon_{x} \\ \varepsilon_{y} \\ \gamma_{x y} \\ \gamma_{x z} \\ \gamma_{y z}\end{array}\right\}$

where $\bar{Q}_{i j}^{(j)}$ - the plane stress-reduced stiffnesses of the j-th orthotropic layer.
When the connections (5) are inserted in the formulas for the intersection forces (4) with respect of the assumed displacement field (1) and (2) as well as the known connections of deformations and displacements, we get the equations that define the dependence of the force and displacement.

The method for determining the reduced stiffness of each layer and stiffness coefficient of layered palates that define the impact of one layer to another, and which are necessary for the calculation of the forces, are determined in the manner shown in the paper [03]. The paper argues that, for the adopted interpolation through the plate thickness, stiffness of layered plates depend on the thickness, the mechanical properties of layers and layers positioning relative to the middle plane of the plate.

$$
A_{i j}=\sum_{k=1}^{N} \int_{z_{j}}^{z_{k+1}} Q_{i j}^{(k)} d z \quad(i, j=1,2,6,4,5)
$$

$$
\begin{aligned}
& D_{i j}^{I J}=\sum_{k=1}^{N} \int_{z_{k}}^{z_{k+1}} Q_{i j}^{(k)} \psi^{I} \psi^{J} d z \quad(i, j=1,2,6) \\
& D_{i j}^{I J}=\sum_{k=1}^{N} \int_{z_{k}}^{z_{k+1}} Q_{i j}^{(k)} \psi,{ }_{z}^{I} \psi,,_{z}^{J} d z \quad(i, j=4,5) \\
& B_{i j}^{J}=\sum_{k=1}^{N} \int_{z_{k}}^{z_{k+1}} Q_{i j}^{(k)} \psi^{J} d z \quad(i, j=1,2,6)
\end{aligned}
$$

$$
B_{i j}^{J}=\sum_{k=1}^{N} \int_{z_{k}}^{z_{k+1}} Q_{i j}^{(k)} \psi,{ }_{z}^{J} d z \quad(i, j=4,5)
$$




\section{ANALYTICAL SOLUTION}

For simply supported layered plate dimensions with $\mathrm{N}$ layers which carry in directions of the $\mathrm{x}$ and $y$ axis, material stiffness $A_{16}, A_{26}, A_{45}, B_{16}{ }_{16}$, $\mathrm{B}_{26}^{\mathrm{J}}, \mathrm{B}_{45}^{\mathrm{J}}, \mathrm{D}^{\mathrm{IJ}}{ }_{16}, \mathrm{D}^{\mathrm{IJ}}{ }_{26}$ and $\mathrm{D}^{\mathrm{IJ}}{ }_{45}$ are equal to zero, equations (6).

The analytical solution to the problem is obtained on the basis of assumed change of componental displacements given in the form of double trigonometric series, [09]:

$$
\begin{aligned}
& u=\sum_{m, n}^{\infty} X_{m n} \cos \alpha x \sin \beta y \\
& v=\sum_{m, n}^{\infty} Y_{m n} \sin \alpha x \cos \beta y \\
& w=\sum_{m, n}^{\infty} W_{m n} \sin \alpha x \sin \beta y \\
& U^{J}=\sum_{m, n}^{\infty} R_{m n}^{J} \cos \alpha x \sin \beta y \\
& V^{J}=\sum_{m, n}^{\infty} S_{m n}^{J} \sin \alpha x \cos \beta y
\end{aligned}
$$

where: $\alpha=\frac{m \pi}{a}, \beta=\frac{n \pi}{b}, J=1, \ldots, n$ while satisfying boundary conditions are:

$$
\begin{array}{ll}
v=w=V^{J}=N_{x}=N_{x}^{J}=0 & x=0, a ; J=1, n \\
u=w=U^{J}=N_{y}=N_{y}^{J}=0 & y=0, b ; J=1, n
\end{array}
$$

The load acting perpendicular to the plane of the plate is shown by trigonometric functions in the form of a double Furie' series:

$$
q(x, y)=\sum_{m, n}^{\infty} Q_{m n} \sin \alpha x \sin \beta y
$$

where $Q_{m n}$ coefficients that depend on the type of load.

When the relations that represent the connection of forces and displacements are inserted into the equations (3) we get a system of equations for the observed problem. For each Furie's pair $(\mathrm{m}$, $n$ ) is obtained a system of $(3+2 n)$ equations with the same number of unknown coefficients $X_{m n}$, $Y_{m n}, Z_{m n}, R_{n m}^{j} i S_{m n}^{j}$. When the obtained decisions are included in the relations (7), we get the values of unknown displacement.

After determining function of overall displacements, the presumed number of trigonometric series members $(m, n)$, the components of the deformation vector, and then the stress vector components for an arbitrary point of layered composite plates are being determined:

$$
\begin{aligned}
& \sigma_{x}(x, y, z)=-\sum_{m, n}^{\infty}\left\{\left[\bar{Q}_{11} \alpha\left(X_{m n}+\sum_{J=1}^{n} R_{m n}^{J} \varphi^{J}(z)\right)+\bar{Q}_{12} \beta\left(Y_{m n}+\sum_{J=1}^{n} S_{m n}^{J} \varphi^{J}(z)\right)\right] \sin \alpha x \sin \beta y\right\} \\
& \sigma_{y}(x, y, z)=-\sum_{m, n}^{\infty}\left\{\left[\bar{Q}_{12} \alpha\left(X_{m n}+\sum_{J=1}^{n} R_{m n}^{J} \varphi^{J}(z)\right)+\bar{Q}_{22} \beta\left(Y_{m n}+\sum_{J=1}^{n} S_{m n}^{J} \varphi^{J}(z)\right)\right] \sin \alpha x \sin \beta y\right\} \\
& \sigma_{x y}(x, y, z)=\bar{Q}_{66} \sum_{m, n}^{\infty}\left\{\left[\beta\left(X_{m n}+\sum_{J=1}^{n} R_{m n}^{J} \varphi^{J}(z)\right)+\alpha\left(Y_{m n}+\sum_{J=1}^{n} S_{m n}^{J} \varphi^{J}(z)\right)\right] \cos \alpha x \sin \beta y\right\}
\end{aligned}
$$

To determine interlayer stresses in the planes $(x$, $z)$ and $(y, z)$ is used approximate, semi-analythic, calculation process with the assumed parabolic distribution along each observed layer $j$ [09]:

$$
\begin{aligned}
& \bar{\sigma}_{x z}^{j}(z)=N_{1}(z) \bar{f}_{1 x}^{j}+N_{2}(z) \bar{f}_{2 x}^{j}+N_{3}(z) \bar{f}_{3 x}^{j} \\
& \bar{\sigma}_{y z}^{j}(z)=N_{1}(z) \bar{f}_{1 y}^{j}+N_{2}(z) \bar{f}_{2 y}^{j}+N_{3}(z) \bar{f}_{3 y}^{j}
\end{aligned}
$$

where:

z - coordinates of the local coordinate system the $j$-th layer of the plate,

$\bar{f}_{i x}^{j}, \bar{f}_{i y}^{j}, i=1,2,3$ - unknown coefficients that represent shear stresses $\sigma_{x z}$ and $\sigma_{y z}$ at the ends and in the middle of the observed layer, $N_{1}(z), N_{2}(z)$ and $\mathrm{N}_{3}(\mathrm{z})$ - one-dimensional quadratic interpolation function.
To determine the unknown coefficients $\bar{f}_{i x}^{j}, \bar{f}_{i y}^{j}$ for each of the shear stresses is necessary to write $3 \mathrm{~N}$ equations. These equations are determined from the following conditions: the shear stresses in the upper and lower fiber of the layer has a value of zero, stresses have the same value on connections of the layers, the condition of the average values of shear stress for each layer $j$ is satisfied, and the values obtained from the constitutuve equation are met.

\section{PROGRAM STRUCTURE}

Schematic representation of ANSLACOP program algorithms based on mathematical model is shown in Figure 2. The program is made up of sub-programs with the following functions: 


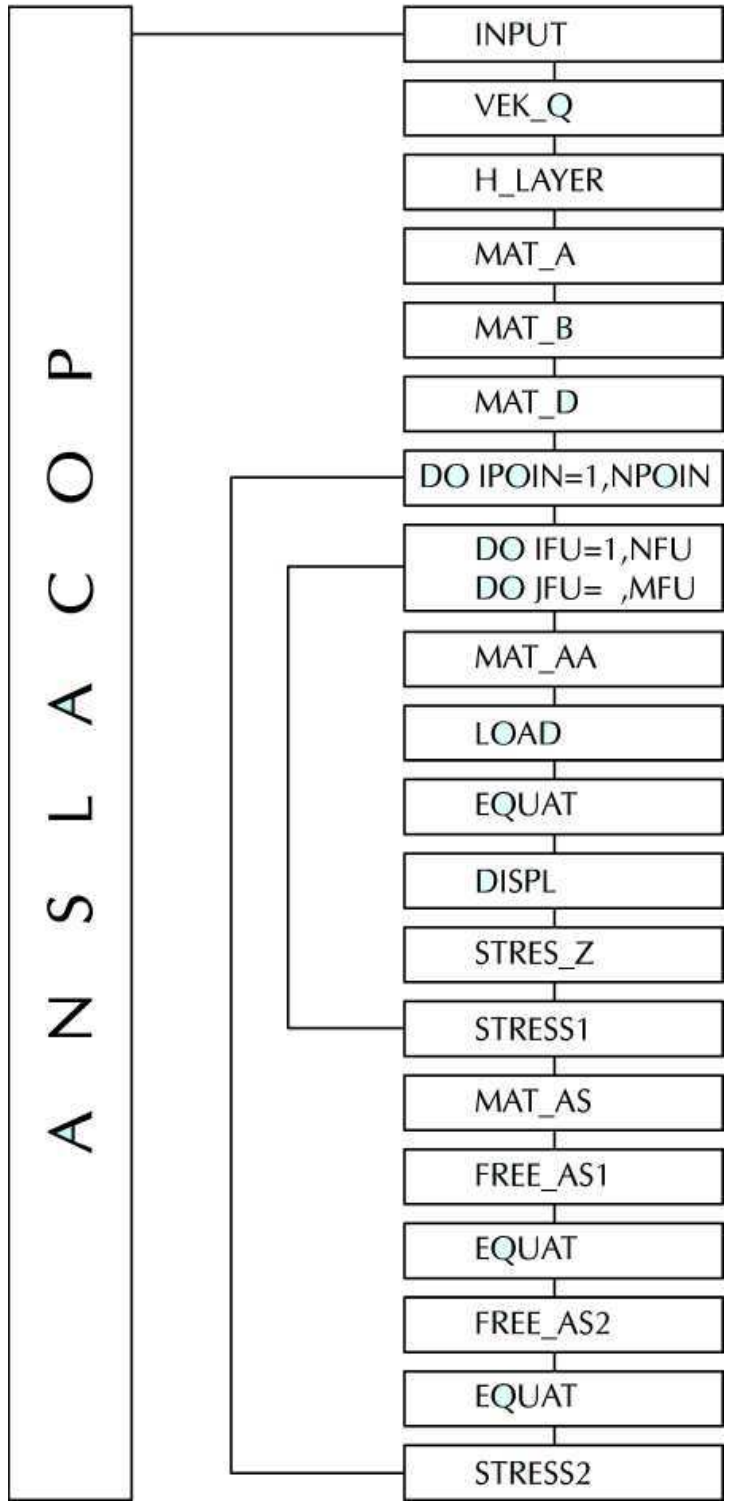

Figure 2: ANSLACOP program algorithm

INPUT - The sub-program INPUT is used for the downloading and preparing of the data necessary for the static analysis of layered composite simply supported plates. Input data are entered into the program over a previously formed INP. dat data file containing the following:

Data group 1: Name of the problem

Data group 2: The number of layers, the number of nodes through the thickness of the layered plate number of nodes in the plane $(x$, $y)$ in which

Data group 3: The width and length of the plate;

Data group 4: Material characteristics of layers ( $E_{i}$-elastic modules, $G_{i j}$ shear modules, $v_{\mathrm{ij}}$ Poisson's ratio);
Data group 5: Angles of layers' orientation;

Data group 6: NFU, MFU - Number of elements of double series

Data group 7: Intensity of load and load index;

Data group 8: Coordinates of nodes through the thickness of the plate;

Data group 9: Coordinates of the nodes inplane ( $\mathrm{x}, \mathrm{y})$.

VEK_Q - The sub-program for each layer $k$ downloads data relating to the material characteristics of layers $E_{i}(i=1,2), G_{i j}(i, j=1,2,3), v_{i j}(i=1,2)$, as well as the angles of the layers' orientation. After that, for each layer $k=1, N$ the calculation of values $Q_{11}$, $Q_{22}, Q_{12}, Q_{44}, Q_{55}, Q_{66}$ is performed as well as transformed material characteristics of layers, [03].

H_LAYER - The sub-program downloads data from the input data file relating to the coordinates of nodes through the thickness of the plate and calculates the thicknesses of layers. Each layer may have different thickness.

MAT_A-The sub-program downloads the results of the sub-program VEK_Q and H_LAYER and calculates the stiffnesses $A_{i j}$ from Eq.(6).

MAT_B - The sub-program downloads the results of the sub-program VEK_Q and H_LAYER and calculates the coefficients of stiffnesses $B_{i j}{ }^{J}$ from Eq. (6).

MAT_D - The sub-program downloads the results of the sub-program VEK_Q and H_LAYER and calculates the coefficients of stiffnesses $D_{i j}{ }^{I J}$ from Eq. (6).

MAT_AA-The sub-program downloads the results of previous sub-program and calculates the coefficients of the governing equations according to Eq. (3).

LOAD - The sub-program downloads the data on the load intensity and the index load (1 or 2) from the input data file and develops the load to a double trigonometric series Eq. (9). Load indexes are defined for uniformly and sinusoidal distributed transverse load.

EQUAT - The sub-program downloads the results of the previous sub-programs, solves the system $(3+2 n)$ and determines the unknown coefficients $X_{m n}, Y_{m n}, W_{m n}, R_{m n}$ and $S_{m n}$ for each pair $(\mathrm{m}, \mathrm{n})$ of the double trigonometric series.

DISPL - The sub-program calculates and sends in the output data file, OUT.dat, values of displacements according to the Eq. (1) and Eq. (7) at the points in the plane $(x, y)$ and through the thickness of the plate. 
STRESS1 - The sub-program calculates stresses in the plane $(x, y)$ according to relations Eq. (10) and sends the results of the calculation in the output data file OUT.dat

MAT_AS, FREE_AS1,EQUAT, FREE_AS2, EQUAT and STRESS2 - The sub-programs calculate the shear stresses $\sigma_{x z}$ and $\sigma_{y z}$ by applying approximate methods shown in this paper, relations Eqs. (11), with the fulfillment of conditions specified in the shown procedure. After the calculation, the values of these stresses are sent in the output data file OUT.dat.

The execution of the program formes the output file OUT.dat with the values of the displacement and the stress at predetermined points simply supported rectangular layered composite plate that are defined in the input file INP.dat.

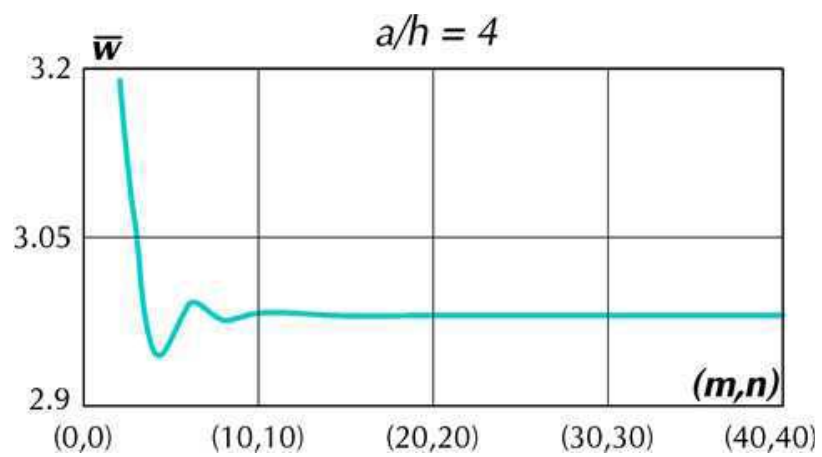

Figure 3: The dimensionless maximum deflection

$(\bar{w})$ versus number of elements of double series

$(m, n)$ for side-to-thickness ratio $a / h=4$ and cross-ply $0 \% 90 \% 0^{\circ}$ laminate

\section{CONVERGENCE AND VERIFICATION OF RESULTS}

The convergence of analytical solutions depending on the number of elements of double series is shown in the example of changes of dimensionless deflection:

$\bar{w}=\frac{100 E_{2}}{q_{0} h s^{4}} w$

in the middle of the three-layer square plate $0 \% / 90 \% 0^{\circ}$ for side-to-thickness ratio $\mathrm{a} / \mathrm{h}=4$ and $\mathrm{a} / \mathrm{h}=10$ and with material properties of a ply $E_{1} /$ $\mathrm{E}_{2}=25, \mathrm{G}_{12}=\mathrm{G}_{13}=0.5 \mathrm{E}_{2}, \mathrm{G}_{23}=0.2 \mathrm{E}_{2}, v_{12}=v_{13}=0.25$, under uniformly distributed load. It is concluded that the analytical solution rapidly converges to the exact solution, Figures 3-4.

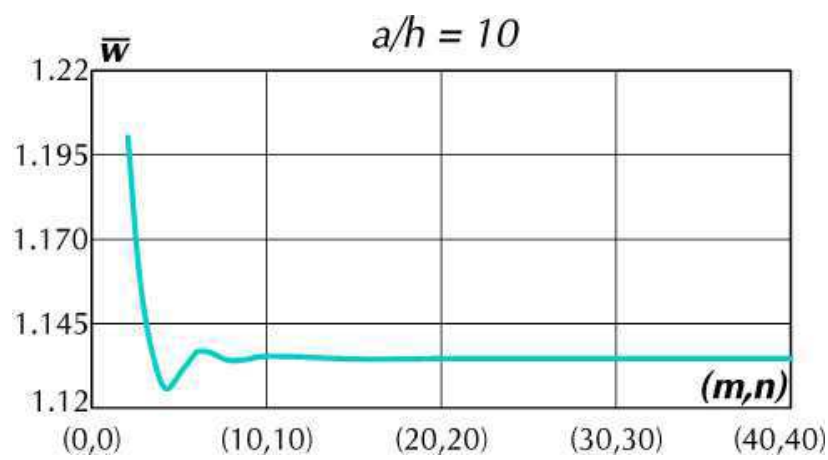

Figure 4: The dimensionless maximum deflection versus number of elements of double series $(m, n)$ for side-to-thickness ratio $a / h=10$ and cross-ply $0 \% 90 \%$ laminate

Table 1: The dimensionless maximum deflection in simpy supported square laminates $0^{\circ} / 90^{\circ} / 0^{\circ}$ under sinusoidally distributed transverse load

\begin{tabular}{|c|c|c|}
\hline $\mathbf{a} / \mathbf{h}$ & $\mathbf{4}$ & $\mathbf{1 0}$ \\
\hline CLPT & 0.4313 & 0.4313 \\
\hline FSDT & 1.9122 & 0.6949 \\
\hline TSDT & 1.9218 & 0.7125 \\
\hline ANSLACOP & 1.9670 & 0.7402 \\
\hline
\end{tabular}

Table 1 contain value of the dimensionless maximum deflection for simpy supported square laminates $0 \% 90 \% 0^{\circ}$ obtained with clasical laminate plate theory (CLPT), first-order shear deformation theory (FSDT), third-order shear deformation plate theory (TSDT) (Reddy [1], page 612, table 11.4-1), and presented program ANSLACOP under sinusoidally distributed transverse load versus side-to-thickness ratio $\mathrm{a} / \mathrm{h}$.

\section{CONCLUSION}

Analytical solution based on a mathematical model of Partial Layerwise Theory obtained by applying the program ANSLACOP converges very fast depending on the adopted number of items in the double trigonometric series and is numerically stable.

The special significance of the presented analytical solution to the problems of bending of anisotropic laminated plates reflects in its use as 
a test solution for the solutions obtained by using numerical methods. Bearing in mind that in the stress-deformation analysis are mainly used software packages (ANSYS, ABAQUS, etc.) based on the finite element method this program can be used as a test solution for the solutions obtained by using these programs for thick and moderately thick simply supported layered composite plates loaded to bending.

\section{REFERENCES}

1) J.N. Reddy,"Theory and analysis of laminated composite plates", Mechanics of Composite Materials and Structures, 1999, 1-79

2) J.N. Reddy: "Mechanics of Laminated Composite Plates - Theory and Analysis", Department of Mechanical Engineering, Texas A\&M University ,1997

3) M. Rakočević, Đ. Vuksanović: "Analitical solution of laminated rectangular composite plates", Monograph "Researches", Editor A.Vujović, Faculty of Civil Engineering, Podgorica, 2002, 253-266
4) M. Rakočević, N.Vatin: "Bending of laminated composite plates", Applied Mechanics and Materials, Vols. 725-726,2015, 667-673

5) M. Rakočević: "Proračun krutosti slojevitih kompozitnih ploča“, Internacionalni naučno stručni skup GNP, Zbornik radova-knjiga 1,2006,20-24

6) M. Rakočević: "Savijanje debelih i umjereno debelih slojevitih kompozitnih ploča", Međunarodna konferencija savremena dostignuća u građevinarstvu, Građevinski fakultet Subotica, Zbornik radova, 2014, 24-25

7) M. Rakočević: "Teorijski modeli slojevitih kompozitnih ploča", Treći internacionalno naučno-stručni skup GNP, Zbornik radova, 2010, 141-146

8) M. Rakočević: „Approximate procedure for calculation of shear stresses $\sigma x z$ and $\sigma y z$ ", Journal of Applied Engineering Science, 10 (1), 2012, 37-42

9) M.Rakočević: " Proračun sastavljenih slojevitih ploča”, Građevinar, 63, 2011, pp. 819-825

Paper sent to revision: 10.02.2016.

Paper ready for publication: 15.03.2016. 


\section{ANALITIČKO REŠENJE ZA JEDNOSTAVNE PODRŽANE LAMINIRANE KOMPOZITNE PLOČE ZASNOVANO NA PARCIJALOJ LAYERWISE TEORIJI}

\section{Marina Rakočević, Univerzitet Crne Gore, Građevinski fakultet, Crna Gora}

Anizotropni sastav slojeva kompozitne ploče zahteva preciznije matematičke i kalkulacijske modele. Primenom REDDI teorije layerwise možemo pokriti širok spektar problema slojevitih kompozitnih ploča sa proizvoljnim rasporedom slojeva kroz debljine. Analitički metod rešavanja jednačine savijanja $u$ Layerwise teoriji se zasniva na pretpostavljenom pomeranju polju u obliku duplog trigonometrijskoj Fourier seriji. Analitički rastvor se može koristiti kao test rastvor za rešenja dobijenim korišćenjem numeričke metode, uključujući metode konačnih elemenata. Za delimičnu Layerwise teorijiu u radu predstavlja jednačine savijanja za laminirani kompozitne ploče i algoritma za izračunavanje ugiba i napona u proizvoljnom preseku jednostavno podržava pravougaonog ploče opterećene sa raspoređenom opterećenju. Na osnovu algoritma predstavljenog u ovom radu, autor je pripremio Fortran program pod nazivom ANSLACOP (analitičko rešenje plastificiranih kompozitne ploče), čija struktura će biti predstavljena u radu. Predstavljeni dobijeni rastvor pomoću ovog programa vrlo brzo konvergira $u$ zavisnosti od usvojenog broja članova dvostrukih trigonometrijeskih serija.

Ključne reči: Laminirane kompozitne ploče, Sloj, Savijanje, Parcijalna Layerwise teorija, Analitičko rešenje 